\title{
The Effect of Operating Conditions on Curcumin Extracted from Turmeric by Hydrothermal Extraction
}

\author{
Mohamad Endy Yulianto ${ }^{1}$, Rizka Amalia ${ }^{1,{ }^{*}}$, Vita Paramita $^{1}$, Indah Hartati ${ }^{2}$, Nissa Ayu Maulinda ${ }^{3}$, and Muhammad Aziz \\ Shulthoni ${ }^{4}$ \\ ${ }^{1}$ Industrial Chemical Engineering, Vocational School, Diponegoro University, Semarang-Indonesia \\ ${ }^{2}$ Department of Chemical Engineering, Faculty of Engineering, Wahid Hasyim University, Semarang Indonesia \\ ${ }^{3}$ Student of Diploma III Chemical Engineering, Vocational School, Diponegoro University, Semarang-Indonesia \\ ${ }^{4}$ Student of Industrial Chemical Engineering, Vocational School, Diponegoro University, Semarang-Indonesia
}

\begin{abstract}
Turmeric has a bioactive compound namely curcuminoid. It has many pharmacology effects such as anticancer, antidiabetic, antioxidant, hypolipidemic, anti-inflammatory, antimicrobial, antifertility, antivenom, anti-coagulant, anti-HIV hepatoprotective, nephroprotective, and anticoagulant properties. To increase the economic value of turmeric, it is necessary to develop a hydrothermal extraction process of turmeric's active compound. The advantages of hydrothermal extraction were inexpensive, abundant availability, high purity, non-toxic, and easy to handle. This research aims to study the effect of operating conditions : temperature $\left(130-150^{\circ} \mathrm{C}\right)$, time $(10-40$ minutes $)$ and solid:liquid ratio $(1: 10$ and $1: 12)$ on the bioactive compounds of turmeric extracted from hydrothermal extraction process. Generally, high extraction yield was obtained at higher extraction temperature $\left(140\right.$ and $\left.150^{\circ} \mathrm{C}\right)$. Under these conditions, with a lower solid : liquid ratio (1:10), high concentration of curcumin is produced. Further, a higher solid : liquid ratio will likely produce the opposite result, except when it operates at low extraction temperature. The high temperature of the pressurized liquid water can reduce the viscosity and surface tension of water so it will increase the diffusion rates and absorption. The higher the solid:liquid ratio, the greater the different concentration between interior and exterior cell, which promote the high efficiency of diffusion process.
\end{abstract}

Keywords: extraction; hydrothermal; turmeric; temperature; solid:liquid

\section{Introduction}

Turmeric (Curcuma domestica Val) has many pharmacology effects such as anticancer, antidiabetic, antioxidant, hypolipidemic, anti-inflammatory, antimicrobial, antifertility, anti-venom, anti-coagulant, anti-HIV hepatoprotective, nephroprotective, and anticoagulant properties[1-4]. The main bioactive component of turmeric which shows the pharmacological properties mentioned above is curcuminoid[1-4]. Curcumonoid consists of $94 \%$ curcumin, $6 \%$ monodexmethoxycurcumin and $1 \%$ bisdesmethoxycurcumin [4-5].

Increasing the added value of commodities can be done through diversification of turmeric into a secondary product (simplicia, extract). The development of "active compound extracts" production process is an effort that will have high competitiveness which can play an important role in increasing the nation's independence towards drug raw material fulfillment. It also increases the product's prices up to 80.8 times higher than the crops [6].

The development of downstream industries in the production of the active compound extract from turmeric and its pharmacological effects was potential for increasing its economic value. There are numerous methods that have been applied in the production of active turmeric extract, including: (i) soxhletation, (ii) percolation, (iii) supercritical fluid extraction, (iv) microwave extraction, and (v) uterine extraction. The extraction process is carried out using various solvents such as ethanol, methanol, acetone, dichloromethane, hexane, $\mathrm{CO} 2$ and water [7-10].

Extraction by soxhletation, percolation, microwave and ultrasonic methods were done effectively using solvents such as ethanol, methanol, aceton, dichloromethane, and hexane. However, it leaves solvent residues that are toxic, cannot be recycled, and difficult to be handling [10-13]. While supercritical extraction with $\mathrm{CO} 2$ and water is very selective and does not leave harmful residual solvent residues. However, the process requires a high cost to supply fluids in supercritical conditions and requires special handling and an expensive price $\left(\mathrm{CO}_{2}\right)[10,14]$.

The alternative extraction process which is considered appropriate for the extraction process have some criteria of solvent: nontoxic, cheap, easy to obtain, abundant availability, high purity, can be recycled, easy to handle, has the polarity approaches with alcohol polarity and low viscosity and surface tension. Extraction using a green solvent in subcritical conditions meets the criteria above. The using of water as a green solvent for extraction in subcritical areas will be effective if it keeps at high

\footnotetext{
* Corresponding author: riz.chemicalia@gmail.com
} 
temperatures. Since at high temperatures, the viscosity and surface tension of the water decreases so it will drive the mass transfer rate, absorption into matrix particles and increase the selectivity [14-16].

The use of water in subcritical areas as green solvents has attracted the attention of researchers from all over the world. Thermodynamically, water in the liquid phase, below its critical point of $374^{\circ} \mathrm{C}$ and $22 \mathrm{MPa}$ is referred as subcritical water. Meanwhile, Hot Compressed Water (HCW) specifically refers to subcritical water above its normal boiling point $100^{\circ} \mathrm{C}$. $\mathrm{HCW}$ or hydrothermal extraction has been successfully used in the extraction process of herbal compounds like cumin [17], Zataria multifora [18], Centela asiactica [19], Thymbra spicata [20], biter melon [21] and oregano[22]. HCW not only functions as a green solvent but can also be used in a selective extraction process. Parameters affect the efficiency of hydrothermal extraction are time and temperature [23]. Thus, this research aims to study the effect of operating condition : temperature $\left(130-150^{\circ} \mathrm{C}\right)$, time (10-40 minutes) and solid:liquid ratio (1:10 and 1:12) on the bioactive compounds of turmeric extracted from hydrothermal extraction process.

\section{Methodology}

\subsection{Materials}

The main material for this research is turmeric, collected from the side products of the herbal medicine industry, "Sido Muncul" Semarang. Nitrogen for supporting hydrothermal extraction and other chemicals used for analysis : acetonitrile, nitrogen, methanol, phosphate buffer, ethanol, distilled water, sodium hydroxide, potassium hydroxide, hydrochloric acid and phenolphtalein indicators were bought from CV. Jurus Maju Semarang. The curcumin standard was obtained from Sigma Aldrich.

\subsection{Apparatus}

The main equipment used in this research was the hydrothermal extractor as shown in Figure 1 and spray dryer. columns at the top or the bottom of the page.

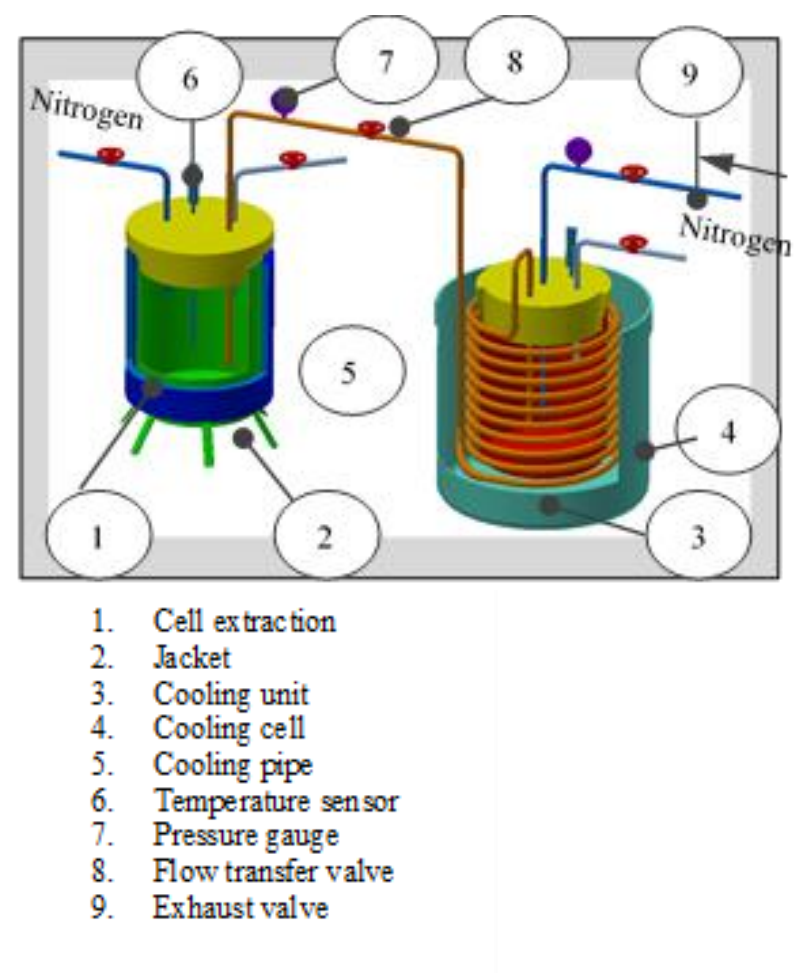

Fig. 1. Hydrothermal Extractor based Green Solvent

\subsection{Hydrothermal extraction of Curcumin from Curcuma domestica Val}

Hydrothermal extraction of curcumin was started by weighing $428 \mathrm{~g}$ of ground Curcuma domestica Val. It was then loaded into the extraction cell. The distilled water of a certain volume was added into the cell. After the cell was securely covered with a lid of stainless steel, nitrogen gas was then passed through to purge air. The hot compressed water extractions were carried out at a temperature of $130-150^{\circ} \mathrm{C}$, and extraction time of $10-40$ minutes at a fixed pressure of 2 bar. Once the extraction process was completed, the extraction mixture was transferred into the cooling cell [24]. Samples were taken and been analyzed its curcumin content.

\section{Results and Analysis}

Hydrothermal extraction of turmeric has been done at a temperature of $130-150^{\circ} \mathrm{C}$ extraction time of $10-40$ minutes, and solid:liquid ratio (1:10 and 1:12) at a fixed pressure of 2 bar. The results showed that at a solid liquid ratio of $1: 10$ and temperature of $130^{\circ} \mathrm{C}$, the concentration of curcumin produced in 10 minutes was $17.25 \% \mathrm{w}$. The concentration of curcumin produced for 20 minutes is higher $(20 \% \mathrm{w})$ when compared to 10 minutes of hydrothermal extraction. However, the concentration of curcumin produced in hydrothermal extraction for 30 and 40 minutes were decreased (Figure 2). Furthermore, at a longer time of extraction, curcumin produced at a temperature of $140^{\circ} \mathrm{C}$ shows a positive trend. Curcumin obtained from hydrothermal extraction carried out at a temperature of $140^{\circ} \mathrm{C}$ and 40 minutes extraction time was $27.69 \% \mathrm{w}$. 

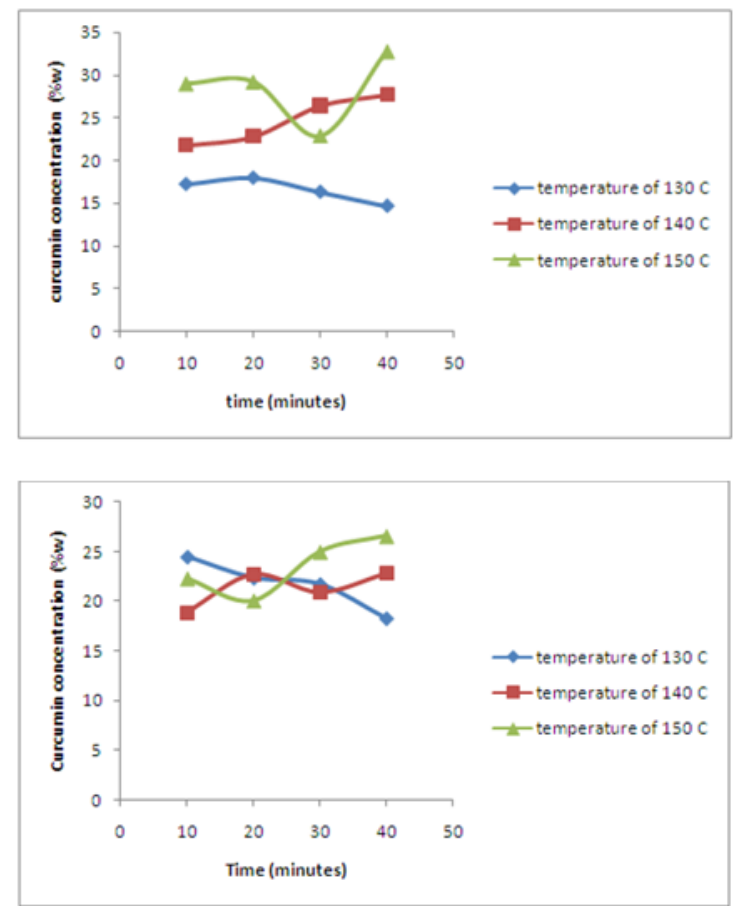

Figure 2. Curcumin produced in Hydrothermal Extraction at Solid:Liquid Ratio (a) 1:10 and (b) 1:12

Hydrothermal extraction which performed at $150^{\circ} \mathrm{C}$ showed fluctuation results of curcumin concentration. Concentration of curcumin produced on hydrothermal extraction carried out at $150^{\circ} \mathrm{C}$ and extraction time of 10 20 minutes were also getting bigger. But at $150^{\circ} \mathrm{C}$ and 30 minutes, the curcumin concentration was decreased and rose again at 40 minutes of extraction time. Nevertheless, Figure 2 shows that in general, the concentration of curcumin produced on hydrothermal extraction at temperatures of 140 and $150^{\circ} \mathrm{C}$ were greater than at $130^{\circ} \mathrm{C}$. This is due to higher temperatures, the viscosity and the water surface tension will decrease. Thus it will force the mass transfer rate and the absorption into particle matrices [16].

The data of curcumin concentration obtained from hydrothermal extraction with a solid liquid ratio 1:12, temperature $130-150^{\circ} \mathrm{C}$ were presented in Figure 3. It is shown that the higher the temperature the higher the concentration of curcumin produced by hydrothermal extraction. For the longer time of extraction, the concentration of curcumin at $130^{\circ} \mathrm{C}$ shows a declining trend. At $130^{\circ} \mathrm{C}$ and 10 minutes, curcumin concentration was $24.48 \% \mathrm{w}$, while at $130^{\circ} \mathrm{C}$ and 40 minutes, it produces $18.03 \% \mathrm{w}$ of curcumin.

In general, the concentration of curcumin produced from the hydrothermal extraction process at $130^{\circ} \mathrm{C}$ with a solid liquid ratio of 1:12 were higher than when operated at solid liquid ratio of 1:10. The higher the solid liquid ratio, the larger the solvent volume to provide much of hydronion, so the extraction process takes place more optimally. However, with the same extraction temperature (140-150 ${ }^{\circ} \mathrm{C}$ ), extraction at $1: 10$ solid liquid ratio produces higher concentration than at 1:12 solid liquid ratio. Extraction using subcritical water was done to separate polysaccharides from Lycium barbarum $L$ [25]. The research shows that increasing ratio of 10 to $25 \mathrm{ml} /$ g, causing extraction yield increases. This is due to the higher the solid liquid ratio, the larger the different concentrations between interior and exterior cell of solvent. As a result, the diffusion process and polysaccharide dissolution by solvent are progressed better.

\section{Conclusion}

Generally, high extraction yield was obtained at higher extraction temperature $\left(140\right.$ and $\left.150^{\circ} \mathrm{C}\right)$. Under these conditions, with a lower solid : liquid ratio (1:10), high concentration of curcumin is produced. Further, a higher solid : liquid ratio will likely produce the opposite result, except when it operates at low extraction temperature. The high temperature of the pressurized liquid water can reduce the viscosity and surface tension of water so it will increase the diffusion rates and absorption. The higher the solid:liquid ratio, the greater the different concentration between interior and exterior cell, which promote the high efficiency of diffusion process.

The authors would like to express their gratitude to LPPM Universitas Diponegoro for its financial support through Riset Pengembangan dan Penerapan (RPP) 2018 under contract No. 474-60/UN7.P4.3/PP/2018.

\section{References}

1. B. Sasikumar, Plant Genetics Resources, 3 (2): 230251. (2005)

2. V. Krup, H. Prakash, A. Harini, Homeopathy and Ayurvedic Medicine, 2, 4 (2013)

3. L. Labban. Int J Pharm Biomed Sci. 5, 1:17-23. (2014)

4. H. Nasri, N. Sahinfad, M. Rafieian, S. Rafieian, M. Shirzad, M.R. Kopaei. Journal of HerbMed Pharmacology. 3, 1: 5-8. (2014)

5. I. Chattopadhyay, K. Biswas, U. Bandyopadhyay and R.K. Banerjee. Curr. Sci. 87: 44-53. (2004)

6. Nurkhasanah. Bahan Obat Alam Sumber Pendapatan Pembangunan. Prosiding Persidangan Antarabangsa Pembangunan Aceh. UKM Bangi. (2006)

7. M.B. Patil, S.V. Tarakal, V.S. Sakpal, S.P. Shewale, R.S. Sakpal. International Journal of Chemical Sciences and Applications. 2, 3: 172-174. (2011)

8. A. Bagchi. IOSR-JESTFT. 1, $3: 01-16$ (2012)

9. A.K. Popuri. International Journal of Innovative Research and Studies. 2, 5 (2013)

10. V.P. Paulucci, R.O. Couto, C.C.C. Teixeira, L.A.P. Freitas. Brazilian Journal of Pharmacognosy. 23, 1:94-100. (2012)

11. R.S. Mohamed, G.A. Mansoori. Food Technology Magazine, (The World Markets Research Centre, London, UK. 2002)

12. H. Purwanto, I. Hartati, L. Kurniasari. Momentum. 6, 2 (2010)

13. I. Hartati, L. Kurniasari, Y. Anas. Indonesia Journal of Pharmacy. 25, 4 (2014) 
14. C.C. Teo, S.N. Tan, J.W.H. Yong, C.S. Hew, E.S. Ong. Journal of Chromatography A, 1217: 24842494. (2010)

15. M.S. Sarip, N.A. Morad, N.A.M. Ali, Y.A.M. Yusof, M.A.C. Yunus. Separation and Purification Technology. 124:141-147. (2014)

16. M.E. Yulianto, P. Kusumo, I. Hartati. Rasayan Journal of Chemistry. 10, 1. (2017)

17. M.H. Eikani, F. Golmohammad, M. Mirza, S. Rowshanzamir. J. Food Process Eng. 30: 255-266. (2007)

18. M. Khajenoori, A.H. Asl, F. Hormozi, M.H. Eikani, H.N. Bidgoli. J. Food Process Eng. 32: 804-816. (2009)

19. W.J. Kim, J. Kim, B. Veriansyah, J.D. Kim, Y.W. Lee, S.G. Oh, R.R. Tjandrawinata. J. Supercrit. Fluids. 48: 211-216. (2009)

20. M.Z. Ozel, F. Gogus, A.C. Lewis. Food Chem. 82: 381-386. (2002)

21. P. Budrat, A. Shotipruk. Sep. Purif. Technol. 66: 125-129. (2009)

22. R. Soto Ayala, M.D. Luque de Castro. Food Chem. 75: 109-113. (2001)

23. J. Wiboonsirikul, S. Adachi. Food Sci. Technol. Res. 14: 319-328. (2008)

24. Z. Chao, Y. Ri-fu, \& Q. Tai-qiu. Separation and Purification Technology. 120:141-147. (2013)

25. M.E. Yulianto, V. Paramita, , I. Hartati, , R. Amalia. Rasayan Journal of Chemistry. 11, 4 : 1564 - 1571 (2018) 